УДК $541.49+546.814$

I. I. Seifullina, E. E. Martsinko, E. V. Afanasenko

Odessa Mechnikov National University, Department of General Chemistry and Polymers, Dvoryanskaya St., 2, Odessa, 65082, Ukraine

\title{
DESIGN AND SYNTHESIS OF NEW HOMO- AND HETEROMETAL COORDINATION COMPOUNDS OF GERMANIUM(IV) FOR PREPARATION OF LOW TOXIC DRUGS WITH A WIDE THERAPEUTIC ACTION
}

Coordination compounds of essential microelement germanium(IV) with metals ( $\mathrm{Mg}, \mathrm{Na}, \mathrm{K}$, $\mathrm{Ca}, \mathrm{Cu}$, etc.) and organic ligands - biocatalysts, antidotes at intoxications and regulators of mineral metabolism in living organism (nicotinic, citric, tartaric, 1-hydroxyethylidendiphosphonic acids, nicotinamide) are synthesized for the first time on the Department of General Chemistry and Polymers of Odessa Mechnikov National University. The favorable activity of the synthesized compounds on cardiovascular and chronic respiratory diseases, senile pneumonia, neuropsychiatric and metabolic disorders, ischemic heart diseases, etc. is described. Thus, the influence of 1-hydroxyethylidendiphosphonatogermanate (medgerm) on CNS, its anxiolytic activity and absence of both hypnotic and myorelaxant effects has been shown. Cardioprotector properties of magnesium hydroxyethylidendiphosphonategermanate as a potential effective and safe drug with the high antihypertensive and antiarrhythmic activity have been found out. The interferoninductive and immunostimulatory activity of germanium(IV) compounds with 1-hydroxyethylidendiphosphonic, nicotinic acids, nicotinamide, pyracetam has been studied. Injection of these drugs (concentration 100-125 $\mu \mathrm{g} / \mathrm{ml}$ ) causes the $100 \%$ delay of cytopathic action of vesicular stomatitis virus in the cell cultures that demonstrates the ability of compounds to increase essentially cells stability.

The perspectives of germanium coordination compounds as interferon inductors and as immune pharmaceuticals for prevention the disbalance of the immune system are reviewed.

Key words: germanium, coordination compounds, bioligands, biological activity, therapeutic action

\section{INTRODUCTION}

The progress in coordination chemistry opens wide prospects for the directed synthesis of biologically active compounds and for the creation of new effective drugs based on coordination compounds of biogenic elements with biologically active ligands. The reason is high biological activity of metal-ion and ligand, which is shown mostly in conditions, maximally close to their state in biological systems of the body. It is known, that combination of biological effects of biogenic elements and physiologically active ligands as part of coordination compounds usually leads to decreasing of toxicity and increasing of metal-ion biological activity comparatively to metal inorganic salts.

According to their functional role in the organism, metallic biocomplexes can be classified as transport agents, accumulators, inert molecule activators and biocatalysts.

Introduction of exogenous complexes can lead to destruction of endogenous functions, to their complexation with the formation of polynuclear compounds and complexes with different ligands, and also leads to independent functioning of biocomplexes with natural origin. The efficiency of the exogenous complexes' activity in this case is determined by the existence of their drug form, synergy of the initial components' effect and by possibility of demonstration of new biological activity. 
The mechanism of coordination compounds' interaction with multicomponent biological systems is highly complicated, but despite the complexity of equilibrium in biological systems, it has been found that introduction of complexes allows to regulate concentration of metal cations in different parts of the organism, to bring them back to needed organic form, to transport drugs into disease focus areas, to remote the toxic influence of cations and several other compounds.

Bioindicators of coordination compounds depend on their chemical and physical properties: the nature of metal complexing agent (valence state, electronic configuration etc.); the nature of ligand and the nature of it's donor functional groups, which take part in the chelation; type of the complex, it's geometrical cis-trans-configuration; kinetic and thermodynamic stability; the own biological activity of metal-ions and ligands, which are used in synthesis, and factors of their synergy and antagonist effect.

It is known that introduction of biometals into the organism as coordination compounds (exogenous complexes) in a form most close to naturally occurred in the biological systems can result in implementation of these compounds functions inherent to biocoordination compounds of natural origin (endogenous complexes). Such exogenous complexes of metals are always less toxic than their inorganic and organic compounds. It is found that introduction of coordination compounds of biometals effectively allows to regulate their concentration in organs in necessary form for organism, to transport medication to the disease sites, to remove the toxic action of cations of metals and other materials.

Originally germanium attracted the interest of researchers due to its presence in herbs, ginseng, garlic, aloes which are widely used in Tibet medicine. In 1950-th doctor $\mathrm{K}$. Asai (Japan) found out germanium in living organisms and then set that the organic compounds of germanium containing germanium-carbon bond positively influence on the human organism, provide the transfer of oxygen in tissues of organism, promote immunity, show antitumor activity. On his theory compounds of germanium in human blood behave like hemoglobin, participate in the process of transfer of oxygen in tissues of organism, warning the development of oxygen insufficiency (hypoxias) at tissue level.

As a result of experiments it has been shown that germanium not only prevents the development of bloody hypoxia (caused by diminishing of amount of hemoglobin and developing at loss of blood, poisoning with carbon oxide, at radiation damages) but also promotes induction of gamma-interferon (which has anti-virus and antitumor activity), immune modulating and radioprotective functions of the lymphatic system [1].

In last few decades, it has been found that various germanium compounds have so wide range of beneficent influence on living organisms together with low toxicity, that it is now possible to characterize Germanium as biomicroelement. Several germanium behavior observations in wildlife can be interpreted as a result of "germanium insufficiency".

Biological researches of germaniumorganic compounds are being done in Institute of Germanium Studies and Germanium Clinic (Japan), Latvian Institute of Organic Synthesis, State Research Institute for Chemistry and Technology of Organoelement Compounds (Russia). A number of compounds, which have antitumor activity and beneficial effect on cardiovascular and chronic respiratory diseases, senile pneumonia, neuropsychiatric and metabolic disorders, some forms of allergy, kidney's, liver's, digestive disorders, hypertension and cataracts have been synthesized.

It is suggested, that the variety of biological properties of the compounds is caused either by their specific features, or by the germanium interferon-inductive and immunestimulating activity. 
Expected mechanism of biological activity of given compounds is associated with atomic electronic structure of germanium. There are 32 electrons in germanium atom, four of which are on the outermost electron shell. When the positively charged ion (or polar molecule) approaches to a such atom, one of the outer electrons tears off. As a result, positively charged ion is formed. Then any free electron around is seeking to fill this loss and at the same time germanium is seeking to regain it's shell. The similar process takes place in living organisms. Germanium atom reacts with charged ions and lowers their electric potential. Perhaps, antitumor activity of germanium compounds is based on this fact: decrease of electric potential in the walls of cancer tumor leads to loss of their activity. Demonstration of analgesic effect is associated with ability of activated germanium atom to bind free electrons. The painful feeling is transmitted from a sick organ to the brain by nerve cells along the special electronic circuit while germanium compounds interrupt movement of electrons. The mechanism of germanium radioprotective action is also associated with it's unique ability to trap electrons and other negatively charged particles. It has been established, that germaniumorganic compounds glue to blood cells and effectively neutralize approaching negatively charged particles and electrons, protecting thereby blood cells from injury.

However as far as more comprehensive researches of bioactive additives containing an organic germanium were carried out, it has been discovered that they show nefro-, neyro- and pulmonary toxicity. FDA drew conclusion, that it is related to the insufficient purity of samples due to trace amouns of initial reagents [2].

Concerning to this, there was an idea to use coordination compounds of germanium with bioactive organic ligands - natural metabolites of human organism for preparation of medicines. Such compounds have substantial advantages comparing to an organic germanium: they have low toxicity, they are water-soluble and form, they can be selected from water solutions, that provides absence of toxic admixtures in a product for a special purpose. It is possible to use one or two bioligands as starting materials, to introduce the second biometal and to get mixed ligand or homo- and heterometal coordination compounds of germanium(IV).

\section{PRINCIPLES OF SYNTHESIS OF LOW-TOXICITY GERMANIUM (IV) COMPOUNDS}

The most perspective way of preparation of medicines containing a biometal is a synthesis of its coordination compounds with bioactive ligands. It is expected that in most cases high pharmacological activity of both metal and ligand is shown up exactly in complex compounds because living organism obviously interacts polymetal and polyligand system in which metals are presented mainly as coordination compounds.

On opinion of many scientists a germanium is a vitally necessary (essencial) microelement. The norm of its consumption in an organic form is no less than a $0,5 \mathrm{mg}$ per a day, meantime human gets hundreds times less with food products. The deficit of germanium in organism results as the state of hypoxia (insufficiency to oxygen) and functioning of all organs and systems is violated because of this state. The results of germanium deficit are the following: syndrome of chronic fatigue, decline of physical and mental capacity, hypovitaminosis, chronic and frequent morbidity, significant risk of development of ischemic heart strokes, osteoporosis, viral diseases and proliferative processes. Unique method to fill germanium deficit in an organism is its additional reception as bioadditive or medication. 
The successful synthesis of germanium coordination compounds having physiological activity is a part of systematical researches of Department of General Chemistry and Polymers of Odessa Mechnikov National University on complexation of germanium with $\mathrm{O}, \mathrm{P}, \mathrm{N}$-containing polyhydric organic acids and other organic ligands, which are drugs themselves (table).

Table

The list of organic ligands

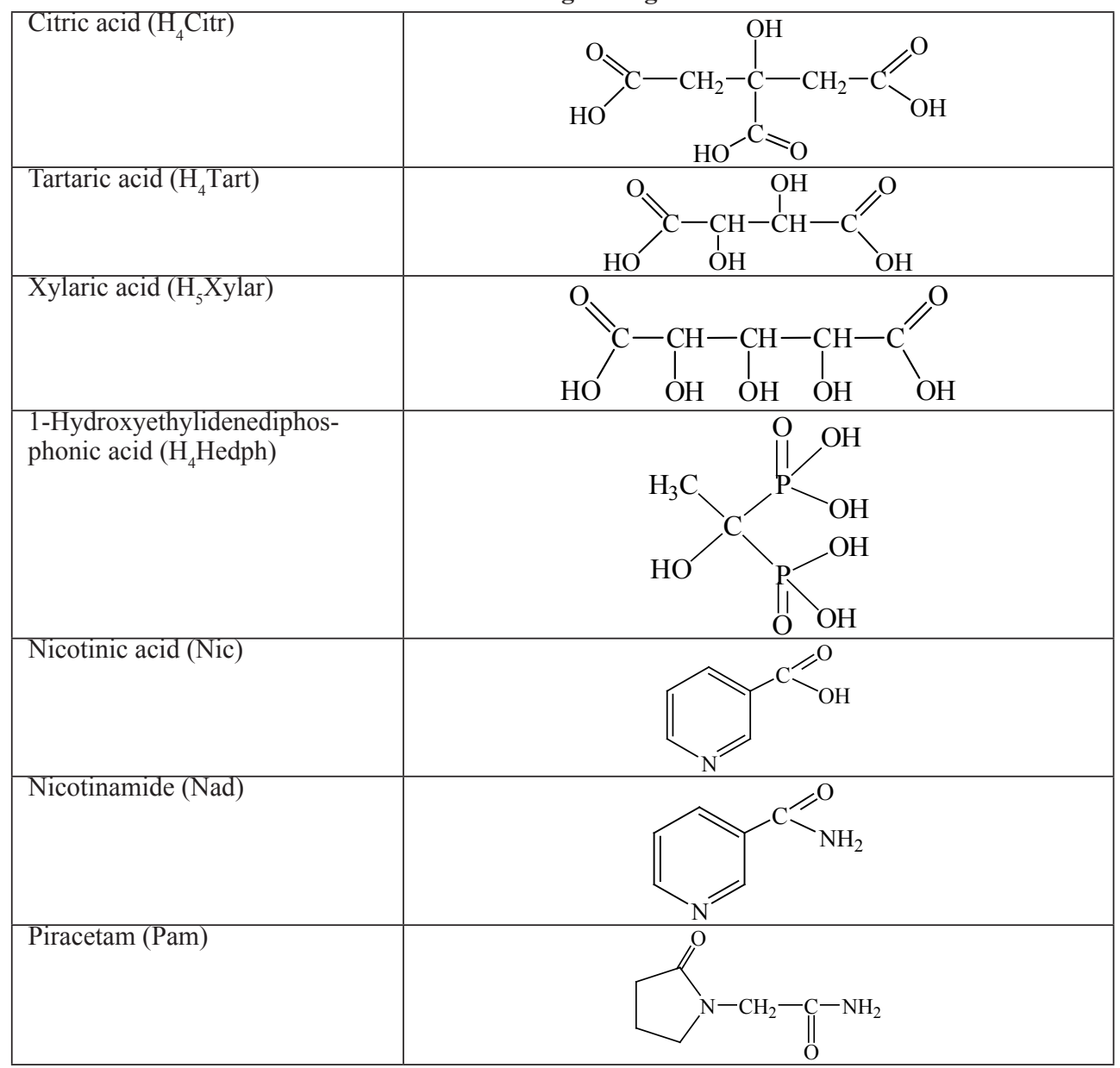

The selection of ligands is based on their specific properties (the ability to act as a biocatalyst, to permeate through the cell membranes, to undergo metabolizm, to dissolve in lipids, etc.), there why these compounds are widely used in medicine as antidotes at intoxications with radioactive metals, as regulators of mineral metabolism, as bactericidal and antiviral drugs, etc.

For example, 1-hydroxyethylidenediphosphonic acid $\left(\mathrm{H}_{4} \mathrm{Hedph}\right)$, which is considered as an analogue of inorganic pyrophosphates - products of transformations in living organisms, has the highest biological activity in the group of phosphonic chelating agents. But, unlike the inorganic pyrophosphates, $\mathrm{H}_{4} \mathrm{Hedph}$ forms strong bonds $\mathrm{P}-\mathrm{C}-\mathrm{P}$ in 
the molecule and doesn't undergo notable enzymatic and acidic hydrolysis, that causes high efficiency of $\mathrm{H}_{4} \mathrm{Hedph}$ as a drug. Therefor this chelating agent relates to a class of moderately toxic substances and doesn't have sensitizing and cumulative properties.

Citric acid is the direct participant of a cycle of threecarbonic acids - process which consists of successive reactions with participation of specific enzymes providing oxidization of basic intermediate products of breaking up of nutritives in a living organism. Chosen as secondary ligands, nicotinic acid and nicotinamide are natural metabolites, vitamins and the second metals in mixed metal complexes ( $\mathrm{Na}, \mathrm{Mg}, \mathrm{Ca}$ and other) are also biometals. They normalize the flow of the broken metabolic processes by participating in biochemical processes like enzymes and coferments. Nicotinamide is an effective therapeutic agent widely used in clinical practice for the treatment of saccharine diabetes, heart, nervous and psychical diseases and also illnesses of organs of digestion, different sorts of poisonings and radial defeats.

Because of complexing properties of mentioned polybasic acids, hydrolysis of germanium has been suppressed, conversion germanium from the molecular to ionized form - stable complex anions, has been done.

The strategy of different variants of the directed synthesis of certain types of highpure coordination compounds of germanium(IV) has been defined taking into consideration economic advantage and ecological safety. The set of conditions of their synthesis: solvent, $\mathrm{pH}$, temperature and concentration, molar ratio of reactive components has been investigated.

The methods of preparation of essentially new homo- and heterometal-containing mixedligand, supramolecular coordination compounds of germanium with the above mentioned accessible, cheap, widely applied in medicine organic molecules and biometals have been developed. These methods are described in detail in papers [3-14].

Complexes have been characterized with the set of physical and chemical methods: element analysis, IR-spectroscopy, thermogravimetry, X-ray powder diffraction, X-ray crystal structure analysis, etc. [3-14].

The composition and structure of coordination sphere of compounds (molecular level of organization) and intramolecular structure of supramolecular associates (nano- or mezolevel of organization) has been defined, and also the relation between composition, chemical structure of complex and its biological activity has been found out.

\section{THE BIOLOGICAL ACTIVITY}

The tests on biological activity (antihypoxic, anti-virus, immune stimulating, cardiotropic, antioxidant, neyrotropic, antialcohol, anticaries, antiinflamating) and toxicity, applied on animals for a number of new coordination compounds of germanium(IV) in many cases have shown hypotoxicity and higher efficiency, compared to analogues used in medical practice.

The screening of a wide range of synthesized germanium coordination compounds has revealed the different types of biological activity and has been made together with specialists from the department of common and clinical pharmacology in Odessa national medical university (Doctor of Medical Science V. I. Kresyun, Doctor of Medical Science V. V. Godowan, Candidates of Medical Science E.F. Shemonayeva, Candidates of Medical Science. Vidavskaya G.G., Candidates of Medical Science. O. L. Tymchishin), the department of pharmacology in Lugansk state medical university (Doctor of Medical Science V.D. Lukyanchuk, N. V. Rysukhina, O. D. Nemyatykh), Institute of a microbi- 
ology and virology of the National Academy of Sciences of Ukraine, Kiev (Doctor of Biological Science L.D. Varbanets, Doctor of Biological Science L.Ya. Spivak, N. M. Zholobak). Results of the studies of biological activity in details are described in papers [15-27]. Some of them are presented:

1. Acute and chronic experiments have proved the safety of 1-hydroxyethylidendiphosphonategermanate derivatives with nicotinic acid, nicotinamide and Mg: $\quad(\mathrm{NicH})_{6}[\mathrm{Ge}(\mu-\mathrm{OH})(\mu-\mathrm{Hedph})]_{6} \quad(\mathbf{1}), \quad(\mathrm{NadH})_{6}[\mathrm{Ge}(\mu-\mathrm{OH})(\mu-\mathrm{Hedph})]_{6} \quad$ (2), $\left[\mathrm{Mg}\left(\mathrm{H}_{2} \mathrm{O}\right)_{6}\right]_{2} \mathrm{H}_{2}[\mathrm{Ge}(\mu-\mathrm{OH})(\mu-\mathrm{Hedph})]_{6}(3)$. Main hepatic and cardiovasotropic effects of these compounds have been studied in vivo and in vitro at different models of pathological conditions. Well as the peculiarities of their distribution and elimination from an animal organism have been established with the help of first elaborated methods of the pharmacokinetic parameters extra-camera analysis. The obtained results substantiate an expediency of practical usage of these biologically active substances (BAS) as safe and potentially high-effective membrane-protecting agents, in complex treatment of the heart and the liver. Magnesium-hydroxyethylidendiphosphonategermanate is recommended for clinical tests as a cardioprotector with high antihypertensive and antiarrhythmic activities, and nicogerm - as a potential effective and safe hepatoprotector $[15,16]$.

2. The properties of new biologically active germanium compounds on the basis of germanium 1-hydroxyethylidendiphosphonate with nicotinic acid, nicotinamide and magnesium 1-3, their influence on intact animals behaviour and electrophysiological processes as well as on neuropathological syndromes have been tested. All three biologically active compounds have been shown to reduce motor activity, decrease muscular tone and possess anticonvulsive activity. Isobolographic analysis of germanium 1-hydroxyethylidendiphosphonate with nicotinamide has revealed its selective potential of valproic acid, carbamazepine, dyphenylhydantoin, topiramate, gabapentin, lamotrigine and levitiracetam to anticonvulsive effect. The conclusion is that new compounds have neuropharmacological activity, that has been shown in both behavioral and electrophysiological animal reactions, change conditions of epileptic and parkinsonian experimental models as change of cortex neurons reactivity in hippocampal slices. It causes expediency of their further thorough-studying as perspective anticonvulsive agents $[17,18]$.

3. Coordination compound $\left[\mathrm{Mg}\left(\mathrm{H}_{2} \mathrm{O}\right)_{6}\right]_{2} \mathrm{H}_{2}[\mathrm{Ge}(\mu-\mathrm{OH})(\mu-\mathrm{Hedph})]_{6}(3)$ have been proved EPR-spectrometrically to have a protective effect on the components of microsomal oxidation (cytochrome $\mathrm{R}-450$ and $\mathrm{Mo}^{5+}$-containing paramagnetic centers) and components of mitochondrial electron transport chain (iron-sulfur proteins and longliving semiquinone radicals) in hepatocytes of rats in crush-syndrome model $[19,20]$.

4. Influence of coordination compound of germanium with nicotinic acid $\left[\mathrm{GeCl}_{2}(\mathrm{Nic})_{4}\right] \mathrm{Cl}_{2}(4)$ on the activity of enzymes in energetic metabolism of blood serum of rats with closed space hypoxia has been investigated. It has been shown that in conditions of modelled pathology the activity of lactate dehydrogenase, glutamate dehydrogenase, glucose-6-phosphate dehydrogenase decreases and activity of creatine kinase increases. It has been proved that preventive injection of germanium complex with nicotinic acid stabilizes the activity of creatine kinase, glucose-6-phosphate dehydrogenase and also increases the activity of lactate dehydrogenase and glutamate dehydrogenase [21].

5. Hepatoprotective properties of a new-synthesized class of biologically active substances - coordination compounds of germanium and such bioligands as nicotinic acid and nicotinamide $\left[\mathrm{GeCl}_{2}(\mathrm{Nic})_{4}\right] \mathrm{Cl}_{2}(4),\left[\mathrm{GeCl}_{2}(\mathrm{Nad})_{4}\right] \mathrm{Cl}_{2}(5)$ have been studied. All the above-mentioned compounds have small toxicity. The hepatoprotective effect on 
toxic hepatitis has been realized by means of decrease of the lipid peroxidation, activity of antiradical protection and normalization of the main structural components of biomembranes. Obtained results have allowed recommending these complexes as membrane protectors in clinical investigations.

6. Coordination compounds of germanium with nicotinamide 5 have been studied in conditions of toxic hepatitis caused by antituberculous drugs. The protective activity of the investigated compounds is due to its ability to prevent the formation of spread membrane pathology by means of significant decrease of free radical generation intensity and accumulation and effective regulation of oxidant-antioxidant homeostasis in the organism of rats with drug-induced hepatitis [22].

7. Series of experiments have allowed comparing estimated hepatoprotective activity of a new complex 1-3 and other BAS of this class such as 1-hydroxyethylydendiphosphonic acid, germanium and magnesium, nicotinic acid, nicotinamide. The researches carried out on a model of galactosamine hepatitis of rat have shown that $\left[\mathrm{Mg}\left(\mathrm{H}_{2} \mathrm{O}\right)_{6}\right]_{2} \mathrm{H}_{2}[\mathrm{Ge}(\mu-\mathrm{OH})(\mu-\mathrm{Hedph})]_{6}(3)$ has the sufficient hepatoprotective action [23].

8. Interferonogenic activity of the coordination compounds of germanium with 1-hydroxyethylidenediphosphonic acid, nicotinic acid, nicotinamide, pyracetam $(\mathrm{NicH})_{6}[\mathrm{Ge}(\mu-\mathrm{OH})(\mu-\mathrm{Hedph})]_{6}(\mathbf{1}),(\mathrm{NadH})_{6}[\mathrm{Ge}(\mu-\mathrm{OH})(\mu-\mathrm{Hedph})]_{6}(\mathbf{2}),(\mathrm{PamH})_{6}[\mathrm{Ge}(\mu-$ $\mathrm{OH})(\mu-\mathrm{Hedph})]_{6}(\mathbf{6})$ has been studied. During the study of the interferonogenic activity synthesized compounds have been shown to cause the production of interferon by cells of sucking-pigs interweaved testicles and to be effective interferon inductors. During the introduction of these preparations (concentrations $100-25 \mu \mathrm{g} / \mathrm{ml}$ ), the $100 \%$ delay of cytopathic action of vesicular stomatitis virus in the cell cultures has been observed, that proves the ability of the synthesized compounds to increase essentially cell resistance towards virus action [24].

9. The new biologically active compound - copper- hydroxyethylidendiphosphonatogermanate (medgerm) $\mathrm{Cu}_{4}\left[\mathrm{Ge}_{6}(\mu-\mathrm{OH})_{4}(\mu-\mathrm{O})_{2}(\mu \text {-Oedph) })_{6} \cdot 40 \mathrm{H}_{2} \mathrm{O}(7)\right.$ its toxicity and pharmacological activity as well as the main mechanisms of action is studied in [25]. For the first time the medgerm's safety has been established. For the first time it has been found that medgerm has dose-dependent influence on CNS, anxiolytic activity, absence of both hypnotic and myorelaxant effects together with analgesic and anti-inflammatory effects, and increasing of hepatic detoxicative function. Its antagonism to amphetamine and synergic activity with 5-oxytryptophan has been revealed firstly that certify the compound influence on monoaminergic central neurotransmission. Its hepatoprotective effect has been revealed firstly in case of prophylactic administration (i.p., $0.4 \mathrm{mg} / \mathrm{kg}$ ) and it is 1.5-2.0 times higher than reference compound essentiale in conditions of acute galactoseamine-induced hepatitis. The mentioned effect has been realized in activation of antioxidant system, inhibition of lipids peroxidation, and decreasing of serum and hepatic cholesterol level. The obtained data has proved reasonability of medgerm application as the potential highly effective and safe medical hepatoprotective agent [25].

10. It has been established that the maximum effect of cerebral protectors in the conditions of a traumatic brain injury is shown by germanium complex with tartaric and nicotinic acid $(\mathrm{HNic})_{2}\left[\mathrm{Ge}_{2}(\mu \text {-Tart })_{2}(\mathrm{OH})_{2}\right] \cdot 4 \mathrm{H}_{2} \mathrm{O}(\mathbf{8})[26]$.

11. Introduction of potassium bis(citrato)germanate $\mathrm{K}_{2}\left[\mathrm{Ge}(\mathrm{HCitr})_{2}\right] \cdot 4 \mathrm{H}_{2} \mathrm{O}(9)$ with medical purposes in the sharp total brain ischemia models has been characterized with maximum antiischemic activity, which has been shown up in a high survival of animals, an inhibition of the process of free-radical oxidation, a normalization of an imbalance 
in the adenylic nucleotides system and the mostly favorable flow of the cerebrovascular insufficiency symptoms, that has been confirmed with the patent of Ukraine [27].

Accordingly to the results of the preliminary researches, a number of coordination compounds of germanium with bioligands show the high biological activity, that has been explained by sinergizm of pharmacological action of germanium, ligands and other metals. Their use is associated with their activity as inductors of interferon - perspective immune pharmacologic medicines for treatment of the immune system disorders.

In accordance with the foregoing, coordination compounds of germanium with bioligands are perspective for design of new effective medications with a wide therapeutic action.

That is the reason why continuation of complementary chemical, physical and biological researches in the area of germanium coordination compounds, which can help to find new perspective bioactive complexes, to reveal regularities and to identify factors, that affect the pharmacological properties, is so actual.

It is particularly important to pay attention to the following issues:

- studying the mechanisms of action of complexes on various processes in the organism, their modeling and forecasting;

- detection of biochemical rates and biochemical reactions, which are responsible for therapeutic effect of medicines based on studied coordination compounds;

- continuation the pharmacokinetic studies.

To solve these tasks successfully, common efforts of chemists, biochemists, pharmacologists, biologists and mathematicians are needed.

Authors express the great gratitude to all colleagues, who took part in carrying out joint chemical and microbiological researches of the considered germanium coordination compounds.

\section{ЛИТЕРАТУРА}

1. Marczynski B. Carcinogenesis as the result of the deficiency of some essential trace elements // Medical Hypotheses. - 1988. - Vol. 4, N4. - P. 239-249. http://dx.doi.org/10.1016/0306-9877(88)90127-2

2. http://www.germaniumsesquioxide.com

3. Seifullina I.I., Martsinko E.E., Aleksandrov G.G. Sergienko V.S., Synthesis, Properties, and Structure of Polynuclear Hydroxyethylidene-1,1-diphosphonatogermanates; Crystal and Molecular Structure of Two Complexes on the Basis of These Compounds // Rus. J. Inorg. Chem. - 2004. - V. 49, № 6. - P. 844-852.

4. Seifullina I.I., Pesaroglo A.G., Minacheva L.Kh., Martsinko E.E., Sergienko V.S. Bis(citrato)germanate Complexes with Organic Cations: Crystal Structure of $(\mathrm{HNic})_{2}\left[\mathrm{Ge}(\mathrm{HCit})_{2}\right] \cdot 3 \mathrm{H}_{2} \mathrm{O} / /$ Rus. J. Inorg. Chem. 2006. - V. 51, № 12. - P. 1892-1899. http://dx.doi.org/10.1134/s0036023606120096

5. Seifullina I.I., Ilyukhin A.B., Martsinko E.E., Sergienko V.S., Chebanenko E.A. Products of Reaction between Bis(citrate)hydroxogermanic Acid and Organic Molecules. Molecular and Crystal Structure of $(\mathrm{HNad})_{2}\left[\mathrm{Ge}(\mathrm{HCit})_{2}\right] \cdot 4 \mathrm{H}_{2} \mathrm{O} / /$ Rus. J. Inorg. Chem. - 2015. - V. 60, № 1. - P. 33-37. http://dx.doi.org/10.1134/ s0036023615010143

6. Martsinko E.E., Seifullina I.I., Minacheva L.Kh., Pesaroglo A.G., Sergienko V.S. Synthesis, Properties, and Molecular and Crystal Structure of Diantipyrylmethanium Bis( $\mu$-Tartrato)dihydroxydigermanate(IV) Tetrahydrate $(\mathrm{HDam})_{2}\left[\mathrm{Ge}_{2}\left(\mathrm{~L}_{-}-\mathrm{L}\right)_{2}(\mathrm{OH})_{2}\right] \cdot 4 \mathrm{H}_{2} \mathrm{O} / /$ Rus. J. Inorg. Chem. - 2008. - V. 53, № 11. - P. 1694-1702. http://dx.doi.org/10.1134/s0036023608110053

7. Pesaroglo A.G., Martsinko E.E., Minacheva L.Kh., Seifullina I.I., Sergienko V.S. The Coordination Polymer Triaquabarium- $-\mathbf{l}$-bis(citrato)germanate Trihydrate: Synthesis, Properties, Molecular and Crystal Structure of $\left\{\left[\mathrm{Ge}\left(\boldsymbol{L}_{-\mathrm{HCit}}\right)_{2} \mathrm{Ba}\left(\mathrm{H}_{2} \mathrm{O}\right)_{3}\right] \cdot 3 \mathrm{H}_{2} \mathrm{O}\right\}_{\mathrm{n}} / /$ Rus. J. Inorg. Chem. - 2010. - V. 55, № 9. - 1366-1372. http://dx.doi. org/10.1134/s0036023610090068

8. Martsinko E.E., Minacheva L.Kh., Pesaroglo A.G., Seifullina I.I., Churakov A.V., Sergienko V.S. Bis(citrato) germanates of Bivalent 3d Metals ( $\mathrm{Fe}, \mathrm{Co}, \mathrm{Ni}, \mathrm{Cu}, \mathrm{Zn}$ ): Crystal and Molecular Structure of $\left[\mathrm{Fe}\left(\mathrm{H}_{2} \mathrm{O}\right)_{6}\right]$ $\left[\mathrm{Ge}(\mathrm{HCit})_{2}\right] \cdot 4 \mathrm{H}_{2} \mathrm{O} / /$ Rus. J. Inorg. Chem. - 2011. - V. 56, № 8. - 1243-1249. http://dx.doi.org/10.1134/ S0036023611080171 
9. Martsinko E.E., Minacheva L.Kh., Chebanenko E.A., Seifullina I.I., Sergienko V.S., Churakov A.V. The Conditions of Formation of Heterometallic Complexes in the $\mathrm{GeCl}_{4}\left(\mathrm{SnCl}_{4}\right)$-Citric Acid- $\mathrm{M}\left(\mathrm{CH}_{3} \mathrm{COO}\right)_{2}-\mathrm{H}_{2} \mathrm{O}$ Systems. The Crystal and Molecular Structures of $\left[\mathrm{M}\left(\mathrm{H}_{2} \mathrm{O}\right)_{6}\right]\left[\mathrm{Ge}(\mathrm{HCit})_{2}\right] \cdot 4 \mathrm{H}_{2} \mathrm{O}(\mathrm{M}=\mathrm{Mg}, \mathrm{Mn}, \mathrm{Co}, \mathrm{Cu}, \mathrm{Zn})$ and $\left[\mathrm{M}\left(\mathrm{H}_{2} \mathrm{O}\right)_{6}\right]\left[\mathrm{Sn}(\mathrm{HCit})_{2}\right] \cdot 4 \mathrm{H}_{2} \mathrm{O}(\mathrm{M}=\mathrm{Mg}, \mathrm{Co}, \mathrm{Ni}) / /$ Rus. J. Inorg. Chem. - 2013. - V. 58, № 5. - 515-522. http:// dx.doi.org/10.1134/s003602361305015x

10. Martsinko E.E., Minacheva L.Kh., Chebanenko E.A., Ilyukhin A.B., Seifullina I.I., Sergienko V.S. Ammonium and Potassium Citratogermanates(IV): Synthesis, Chemical Compositions, and Structures. The Crystal Structures of $\left(\mathrm{NH}_{4}\right)\left[\mathrm{Ge}(\mathrm{OH})\left(\mathrm{H}_{2} \mathrm{Cit}\right)_{2}\right] \cdot \mathrm{H}_{2} \mathrm{O}$ and $\mathrm{K}_{4}\left[\mathrm{Ge}(\mathrm{HCit})_{2}\left(\mathrm{H}_{2} \mathrm{Cit}\right)\right] \cdot 3 \mathrm{H}_{2} \mathrm{O} / /$ Rus. J. Coord. Chem. - 2013. V. 39, № 9. - 629-635. http://dx.doi.org/10.1134/s1070328413090054

11. Minacheva L.Kh., Seifullina I.I., Ilyukhin A.B., Martsinko E.E., Sergienko V.S., Chebanenko E.A., Churakov A.V.Strategy for the Synthesis of Di- and Polymer Tartratogermanates with Single-Charge Cations. Crystal Structures of $\mathrm{K}_{2}\left[\mathrm{Ge}_{2}(\mathrm{OH})_{2}(\boldsymbol{\mu}-\mathrm{Tart})_{2}\right] \cdot 4.5 \mathrm{H}_{2} \mathrm{O}$ and $\left(\mathrm{NH}_{4}\right)_{2 n}\left[\mathrm{Ge}_{2}(\mu-\mathrm{O})(\boldsymbol{\mu}-\mathrm{Tart})_{2}\right]_{n} \cdot n \mathrm{MeCN} \cdot n \mathrm{H}_{2} \mathrm{O} / /$ Rus. J. Coord. Chem. - 2013. - V. 39, № 11. - 751-757. http://dx.doi.org/10.1134/s1070328413110043

12. Martsinko E.E., Pesaroglo A.G., Minacheva L.Kh., Seifullina I.I. et al. Synthesis, Properties, and Molecular and Crystal Structure of Hexaaquacopper(IV) Bis(diaquacuprato- $\mu_{3}$-trihydroxyglutarato)germanate(IV) Dihydrate $\left[\mathrm{Cu}\left(\mathrm{H}_{2} \mathrm{O}\right)_{6}\right]\left[\mathrm{Ge}\left(\mu_{3}-\mathrm{Thgl}\right)_{2}\left\{\mathrm{Cu}\left(\mathrm{H}_{2} \mathrm{O}\right)_{2}\right\}_{2}\right] 2 \mathrm{H}_{2} \mathrm{O} / /$ Rus. J. Inorg. Chem. - 2011. - V. 56, № 2. - P. 190-196. http:// dx.doi.org/10.1134/s0036023611020197

13. Martsinko E.E., Minacheva L.Kh., Seifullina I.I. et al. Heteronuclear Alkali Metal bis( $\mu$-Trihydroxoglutarato) dihydroxodigermanates(IV). The Crystal and Molecular Structure of $\mathrm{K}_{4}\left[\mathrm{Ge}_{2}(\mu-\mathrm{Thgl})_{2}(\mathrm{OH})_{2}\right] \cdot 4 \mathrm{H}_{2} \mathrm{O} / / \mathrm{Rus}$. J. Inorg. Chem. - 2012. - V. 57, № 3. - P. 343-349. http://dx.doi.org/10.1134/s0036023612030199

14. Martsinko E.E., Pesaroglo A.G., Minacheva L.Kh., Seifullina I.I. et al. Synthesis and Characterization of Cobalt(II) and Manganese(II) Xylaratogermanates: The Molecular and Crystal Structures of the $\left[\mathrm{M}_{(}\left(\mathrm{H}_{2} \mathrm{O}\right)_{6}\right]$ $\left[\mathrm{G}_{\mathrm{e}}\left(\mu_{3}-\mathrm{L}\right)_{2}\left\{\mathrm{M}\left(\mathrm{H}_{2} \mathrm{O}\right)_{2}\right\}_{2}\right] \cdot 4 \mathrm{H}_{2} \mathrm{O} \cdot n \mathrm{CH}_{3} \mathrm{CN}$ Complexes $(\mathrm{M}=\mathrm{Co}, \mathrm{n}=0 ; \mathrm{M}=\mathrm{Mn}, \mathrm{n}=1) / /$ Rus. J. Inorg. Chem. 2013. - V. 58, № 2. - P. 152-159. http://dx.doi.org/10.1134/s0036023613020174

15. Pat. 19965 Ukraine, (51) МПК (2006), А61K 31/19 (2006.01), A61K 33/12 (2006.01), A61K 33/24. Magnesium-oxyethylidendiphosphonate germanate which is characterized by vasotropic action / V.V. Godovan, V.Y. Kresyun, I.I. Seifullina. - Bull. №1. 15.01.2007.

16. Pat. 20658 Ukraine, (51) МПК (2007), А61K 31/19 (2007.01), A61K 33/00. Biologically active antiarrhythmical substance ,germacord” / V.V. Godovan, V.Y. Kresyun, I.I. Seifullina. - Bull. №2. 15.02.2007.

17. Kresyun V.Y., Seifullina I.Y., Vidavska G.G., Shemonayeva K.F. Perspectives of new Oxyethylidendiphosphonate acid-based pharmaceutical preparations // Medical Chemistry. - 2004. - Vol.6, No 3. - P.133-138.

18. Voloshenkov D.B. Neurotropic effects of coordination compounds on the base of germanium oxyethylendiphosphonate with nicotinic acid, nicotinamide and magnesium. - A manuscript. Thesis for a scientific degree of candidate of medical sciences in speciality 14.03.05 - pharmacology. - Odessa State Medical University Ministry of Health Care of Ukraine. - Odessa, 2008. - P.157.

19. Pat. 36684 Ukraine, (51) МПК (2008), A61K31/045, A61K33/00. Method of detoxication of organism at endotoxicosis of posttraumatic origin by means of coordination compound on the base of germanium, magnesium and oxyethylidenediphosphonic acid / V.D. Lukjanchuk, I.I. Seifullina, N. V. Risukhina, E.E. Martsinko. - Bull. №21. 10.11.2008.

20. Lukyanchuk V.D., Seifullina I.I., Risukhina N.V. EPR-spectrometric analysis of protective action of coordination compound of germanium with magnesium and oxyethylidendiphosphonic acid in conditions of crushsyndrome // J. Academy of Medical Sciences of Ukraine. - 2008. - Vol.14, No 3 - P. 593-601.

21. Pat. 613475A Ukraine, (19)UA, (51) МПК (2003), A61K31/455, A61K33/00. Coordination compounds of germanium with nicotinic acid having antihypoxant activity / I.I. Seifullina, V.D. Lukjanchuk, O.D. Nemyalyk.Bull. №17.11.2003.

22. Pat. 22954 Ukraine, (19)UA, (51) MПК (2006), G01N 33/576, A61K 39/29. Method of pharmaceutical correction of toxic medicinal hepatitis / V.D. Lukjanchuk, M.A. Vnukova, I.I. Seifullina, O.O. Shpulina, V.N. Tkachenko. - Bull. №5. 25.04.2007.

23. Godovan V.V., Kresyun V.Y., Seifullina I.Y. Comparative Pharmacological Activity of New Biologically Active Substances - Derivatives of Diphosphonate Acids // Integrative Anthropology. International Medical and Philosophical Magazine. - 2007. - No. 2(10). - P. 13-17.

24. Seifullina I.I., Martsinko E.E., Spivak N. Ya., Zholobak N.M. The polymolecular aggregates of nicotinic acid, nicotinamide, pyracetam with oxyethylidenediphosphonatohydroxygermanium acid and their interferonogenic activities // Abstr. Rep. XX Ukr. Conf. Organic Chemistry. - Odessa, 2004. P. 443.

25. Pat. 66392 Ukraine, (51) МПК (2011.01), A61P 1/16 (2006.01), А61K 31/30 (2006.01), A61K 9/14 (2006.01). Medgerm as biologically active hepatoprotective agent / O.L. Tymchishin, V.V. Godovan, V.Y. Kresyun, I.I. Seifullina, E.E. Martsinko. - Bull. №24. 26.11.2011. 
26. Pat. 20555 Ukraine, (19)UA, (51) МПК (2006), А61K 35/30. The method of pharmacological correction of a craniocereberal trauma / Lukyanchuk V.D., Seyfullina I.I., Vysotsky A.A., Martsinko E.E., Pesaroglo O.G. Bull. №1. 15.01.2007.

27. Pat. 71812 Ukraine, МПК (2012.01) A61P 9/00 A61K 33/00. Potassium bis(citrato)germanate (IV) that shows the antiischemic activity / V.D. Lukyanchuk, I.O. Zhitina, I.I. Seifullina, E.E. Martsinko. - Bull. № 14.

Стаття надійшла до редакції 15.07.15

I. І. Сейфуліна, О. Е. Марцинко, Е. В. Афанасенко

Одеський національний університет імені I.I. Мечникова, кафедра загальної хі-мії та полімерів, вул. Дворянська, 2, м. Одеса, 65082, Україна

\title{
МОДЕЛЮВАННЯ ТА СИНТЕЗ НОВИХ ГОМО- ТА ГЕТЕРОМЕТАЛІЧНИХ КООРДИНАЦІЙНИХ СПОЛУК ГЕРМАНІЮ(IV) ДЛЯ СТВОРЕННЯ НИЗЬКОТОКСИЧНИХ ПРЕПАРАТІВ ШИРОКОЇ ТЕРАПЕВТИЧНОЇ ДІЇ
}

\begin{abstract}
В оглядовій статті розглянуті вперше синтезовані на кафедрі загальної хімії та полімерів OHУ ім. I.I. Мечникова гомо- і гетерометалічні координаційні сполуки германію(IV) 3 біолігандами (нікотинова, лимонна, винна, 1-гідроксіетилідендифосфонова кислоти, нікотінамід) - природними метаболітами організму людини, широко застосовуваними у медицині. Охарактеризовано вплив сполук германію(IV) на процеси життєдіяльності тварин і людини, встановлена їх антигіпоксична, імуностимулююча, кардіотропна, антиоксидантна, нейротропна, протизапальна та ін. активність. Показані перспективи подальшого синтезу та вивчення координаційних сполук германію(IV) з біологічно активними лігандами.
\end{abstract}

Ключові слова: германій, координаційні сполуки, біоліганди, біологічна активність, терапевтична дія

И. И. Сейфуллина, Е. Э. Марцинко, Э. В. Афанасенко

Одесский национальный университет, кафедра общей химии и полимеров

ул. Дворянская 2, Одесса, 65082, Украина

\section{МОДЕЛИРОВАНИЕ И СИНТЕЗ НОВЫХ ГОМО- И ГЕТЕРОМЕТАЛЛИЧЕСКИХ КООРДИНАЦИОННЫХ СОЕДИНЕНИЙ ГЕРМАНИЯ(IV) ДЛЯ СОЗДАНИЯ НИЗКОТОКСИЧНЫХ ПРЕПАРАТОВ ШИРОКОГО ТЕРАПЕВТИЧЕСКОГО ДЕЙСТВИЯ}

В обзорной статье рассмотрены впервые синтезированные на кафедре общей химии и полимеров ОНУ имени И.И. Мечникова гомо- и гетерометаллические координационные соединения германия(IV) с биолигандами (никотиновая, лимонная, винная, 1-гидроксиэтилидендифосфоновая кислоты, никотинамид) - естественными метаболитами организма человека, широко применяемыми в медицине. Охарактеризовано влияние соединений германия(IV) на процессы жизнедеятельности животных и человека, установлена их антигипоксическая, иммуностимулирующая, кардиотропная, антиоксидантная, нейротропная, противовоспалительная и др. активность. Показаны перспективы дальнейшего синтеза и изучения координационных соединений германия(IV) c биологически активными лигандами.

Ключевые слова: германий, координационные соединения, биолиганды, биологическая активность, терапевтическое действие 


\section{REFERENCES}

1. Marczynski B. Carcinogenesis as the result of the deficiency of some essential trace elements. Medical Hypotheses, 1988, vol. 4, no 4, pp. 239-249. http://dx.doi.org/10.1016/0306-9877(88)90127-2

2. http://www.germaniumsesquioxide.com

3. Seifullina I.I., Martsinko E.E., Aleksandrov G.G. Sergienko V.S. Synthesis, Properties, and Structure of Polynuclear Hydroxyethylidene-1,1-diphosphonatogermanates; Crystal and Molecular Structure of Two Complexes on the Basis of These Compounds. Rus. J. Inorg. Chem, 2004, vol. 49, no 6, pp. 844-852.

4. Seifullina I.I., Pesaroglo A.G., Minacheva L.Kh., Martsinko E.E., Sergienko V.S. Bis(citrato)germanate Complexes with Organic Cations: Crystal Structure of $(\mathrm{HNic})_{2}\left[\mathrm{Ge}(\mathrm{HCit})_{2}\right] \cdot 3 \mathrm{H}_{2} \mathrm{O}$. Rus. J. Inorg. Chem, 2006, vol. 51, no 12, pp. 1892-1899. http://dx.doi.org/10.1134/s0036023606120096

5. Seifullina I.I., Ilyukhin A.B., Martsinko E.E., Sergienko V.S., Chebanenko E.A. Products of Reaction between Bis(citrate)hydroxogermanic Acid and Organic Molecules. Molecular and Crystal Structure of $(\mathrm{HNad})_{2}\left[\mathrm{Ge}(\mathrm{HCit})_{2}\right] \cdot 4 \mathrm{H}_{2} \mathrm{O}$. Rus. J. Inorg. Chem., 2015, vol. 60, no 1, pp. 33-37. http://dx.doi.org/10.1134/ s0036023615010143

6. Martsinko E.E., Seifullina I.I., Minacheva L.Kh., Pesaroglo A.G., Sergienko V.S. Synthesis, Properties, and Molecular and Crystal Structure of Diantipyrylmethanium Bis( $\mathbf{- 1}$-Tartrato)dihydroxydigermanate(IV) Tetrahydrate (HDam) ${ }_{2}\left[\mathrm{Ge}_{2}(\mathrm{H}-\mathrm{L})_{2}(\mathrm{OH})_{2}\right] \cdot 4 \mathrm{H}_{2} \mathrm{O}$. Rus. J. Inorg. Chem, 2008, vol. 53, no 11, pp. 1694-1702. http://dx.doi.org/10.1134/s0036023608110053

7. Pesaroglo A.G., Martsinko E.E., Minacheva L.Kh., Seifullina I.I., Sergienko V.S. The Coordination Polymer Triaquabarium-k-bis(citrato)germanate Trihydrate: Synthesis, Properties, Molecular and Crystal Structure of $\left\{\left[\mathrm{Ge}(-\mathrm{l}-\mathrm{HCit})_{2} \mathrm{Ba}\left(\mathrm{H}_{2} \mathrm{O}\right)_{3}\right] \cdot 3 \mathrm{H}_{2} \mathrm{O}_{n}\right.$. Rus. J. Inorg. Chem., 2010, vol. 55, no 9, pp. 1366-1372. http://dx.doi. org/10.1134/s0036023610090068

8. Martsinko E.E., Minacheva L.Kh., Pesaroglo A.G., Seifullina I.I., Churakov A.V., Sergienko V.S. Bis(citrato) germanates of Bivalent 3d Metals (Fe, $\mathrm{Co}, \mathrm{Ni}, \mathrm{Cu}, \mathrm{Zn})$ : Crystal and Molecular Structure of $\left[\mathrm{Fe}\left(\mathrm{H}_{2} \mathrm{O}\right)_{6}\right]$ [Ge(HCit) $\left.{ }_{2}\right] \cdot 4 \mathrm{H}_{2} \mathrm{O}$. Rus. J. Inorg. Chem., 2011, vol. 56, no 8, pp. 1243-1249. http://dx.doi.org/10.1134/ s0036023611080171

9. Martsinko E.E., Minacheva L.Kh., Chebanenko E.A., Seifullina I.I., Sergienko V.S., Churakov A.V. The Conditions of Formation of Heterometallic Complexes in the $\mathrm{GeCl}_{4}(\mathrm{SnCl})$-Citric Acid-M(CH$\left.{ }_{3} \mathrm{COO}\right)_{2}-\mathrm{H}_{2} \mathrm{O}$

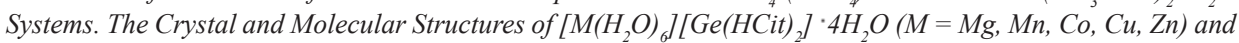
$\left[\mathrm{M}\left(\mathrm{H}_{2} \mathrm{O}\right)_{6}\right]\left[\mathrm{Sn}(\mathrm{HCit})_{2}\right] \cdot 4 \mathrm{H}_{2} \mathrm{O}(\mathrm{M}=\mathrm{Mg}$, Co, Ni). Rus. J. Inorg. Chem., 2013, vol. 58, no 5, pp. 515-522. http:// dx.doi.org/10.1134/s003602361305015x

10. Martsinko E.E., Minacheva L.Kh., Chebanenko E.A., Ilyukhin A.B., Seifullina I.I., Sergienko V.S. Ammonium and Potassium Citratogermanates(IV): Synthesis, Chemical Compositions, and Structures. The Crystal Structures of $\left(\mathrm{NH}_{4}\right)\left[\mathrm{Ge}(\mathrm{OH})\left(\mathrm{H}_{2} \mathrm{Cit}\right)_{2}\right] \cdot \mathrm{H}_{2} \mathrm{O}$ and $\mathrm{K}_{4}\left[\mathrm{Ge}(\mathrm{HCit})_{2}\left(\mathrm{H}_{2} \mathrm{Cit}\right)\right] \cdot 3 \mathrm{H}_{2} \mathrm{O}$. Rus. J. Coord. Chem., 2013 , vol. 39, no 9, pp. 629-635. http://dx.doi.org/10.1134/s1070328413090054

11. Minacheva L.Kh., Seifullina I.I., Ilyukhin A.B., Martsinko E.E., Sergienko V.S., Chebanenko E.A., Churakov A.V. Strategy for the Synthesis of Di- and Polymer Tartratogermanates with Single-Charge Cations. Crystal Structures of $\mathrm{K}_{2}\left[\mathrm{Ge}_{2}(\mathrm{OH})_{2}(\mathrm{k}-\mathrm{-Tart})_{2}\right] \cdot 4.5 \mathrm{H}_{2} \mathrm{O}$ and $\left(\mathrm{NH}_{4}\right)_{2 n}\left[\mathrm{Ge} e_{2}(\mathrm{k}-\mathrm{O})(\mathrm{k}-\mathrm{Tart})_{2}\right]_{n} \cdot n \mathrm{MeCN} \cdot n \mathrm{H}_{2} \mathrm{O}$. Rus. J. Coord. Chem., 2013, vol. 39, no 11, pp. 751-757. http://dx.doi.org/10.1134/s1070328413110043

12. Martsinko E.E., Pesaroglo A.G., Minacheva L.Kh., Seifullina I.I. et al. Synthesis, Properties, and Molecular and Crystal Structure of Hexaaquacopper(IV) Bis(diaquacuprato- $\mu_{3}$-trihydroxyglutarato)germanate(IV) Dihydrate $\left[\mathrm{Cu}\left(\mathrm{H}_{2} \mathrm{O}\right)_{6}\right]\left[\mathrm{Ge}\left(\mathrm{\mu}_{3}-\mathrm{Thgl}\right)_{2}\left\{\mathrm{Cu}\left(\mathrm{H}_{2} \mathrm{O}\right)_{2}\right\}_{2}\right] 2 \mathrm{H}_{2} \mathrm{O}$ Rus. J. Inorg. Chem., 2011, vol. 56, no 2, pp. 190-196. http://dx.doi.org/10.1134/s0036023611020197

13. Martsinko E.E., Minacheva L.Kh., Seifullina I.I. et al. Heteronuclear Alkali Metal bis( $\mu$ Trihydroxoglutarato) dihydroxodigermanates(IV). The Crystal and Molecular Structure of $\mathrm{K}_{4}\left[\mathrm{Ge}_{2}(\square-\mathrm{Thgl})_{2}(\mathrm{OH})_{2}\right] \cdot 4 \mathrm{H}_{2} \mathrm{O}$. Rus. J. Inorg. Chem., 2012, vol. 57, no 3, pp. 343-349. http://dx.doi.org/10.1134/s0036023612030199

14. Martsinko E.E., Pesaroglo A.G., Minacheva L.Kh., Seifullina I.I. et al. Synthesis and Characterization of Cobalt(II) and Manganese(II) Xylaratogermanates: The Molecular and Crystal Structures of the $\left[\mathrm{M}\left(\mathrm{H}_{2} \mathrm{O}\right)_{6}\right]$ $\left[\mathrm{G}_{e}\left(\mu_{3}-\mathrm{L}\right)_{2}\left\{\mathrm{M}\left(\mathrm{H}_{2} \mathrm{O}\right)_{2}\right\}_{2}\right] \cdot 4 \mathrm{H}_{2} \mathrm{O} \cdot n \mathrm{CH}_{3} \mathrm{CN}$ Complexes $(M=C o, n=0 ; M=M n, n=1)$. Rus. J. Inorg. Chem., 2013, vol. 58, no 2, pp. 152-159. http://dx.doi.org/10.1134/s0036023613020174

15. Pat. 19965 Ukraine, (51) МПК (2006), А61K 31/19 (2006.01), A61K 33/12 (2006.01), A61K 33/24. Magnesium-oxyethylidendiphosphonate germanate which is characterized by vasotropic action / V.V. Godovan, V.Y. Kresyun, I.I. Seifullina. - Bull. №1. 15.01.2007.

16. Pat. 20658 Ukraine, (51) МПК (2007), A61К 31/19 (2007.01), A61K 33/00. Biologically active antiunrhythmical substance „germacord” / V.V. Godovan, V.Y. Kresyun, I.I. Seifullina. - Bull. №2. 15.02.2007. 
17. Kresyun V.Y., Seifullina I.Y., Vidavska G.G., Shemonayeva K.F. Perspectives of new Oxyethylidendiphosphonate acid-based pharmaceuticals creation. Medical Chemistry, 2004, vol. 6, no 3, pp.133-138.

18. Voloshenkov D.B. Neurotropic effects of coordination compounds on the base of germanium oxyethylendiphosphonate with nicotinic acid, nicotinamide and magnesium. - A manuscript. Thesis for a scientific degree of kandidate of medical sciences in speciality 14.03.05 - pharmacology. - Odessa State Medical University Ministry of Health Care of Ukraine. Odessa, 2008. pp 157.

19. Pat. 36684 Ukraine, (51) МПК (2008), А61К31/045, А61К33/00. Method of detoxication of organism at endtoxicosis of posttraumatic origin by means of coordination compound on the base of germanium, magnesium and oxyethylidenediphosphononate acid / V.D. Lukjanchuk, I.I. Seifullina, N.V. Risukhina, E.E. Martsinko. Bull. №21. 10.11.2008.

20. Lukyanchuk V.D., Seifullina I.I., Risukhina N.V. EPR-spectrometric analysis of protective action of coordination compound of germanium with magnesium and oxyethylidendiphosphonic acid in conditions of crush-syndrome. J. Academy of Medical Sciences of Ukraine, 2008, vol. 14, no 3, pp. 593-601.

21. Pat. 613475A Ukraine, (19)UA, (51) MПК (2003), A61K31/455, A61K33/00. Coordination compounds of germanium with nicotinic acid having antihypoxant activity / I.I. Seifullina, V.D. Lukjanchuk, O.D. Nemyalyk. Bull. №17.11.2003.

22. Pat. 22954 Ukraine, (19)UA, (51) MПК (2006), G01N 33/576, А61K 39/29. Method of pharmaceutical correction of toxic medicinal hepatitis / V.D. Lukjanchuk, M.A. Vnukova, I.I. Seifullina, O.O. Shpulina, V.N. Tkachenko. - Bull. №5. 25.04.2007.

23. Godovan V.V., Kresyun V.Y., Seifullina I.Y. Comparative Pharmacological Activity of New Biologically Active Substances - Derivatives of Diphosphonate Acids. Integrative Anthropology. International Medical and Philosophical Magazine, 2007, no 2(10), pp.13-17.

24. Seifullina I.I., Martsinko E.E., Spivak N. Ya., Zholobak N.M. The polymolecular aggregates of nicotinic acid, nicotinamide, pyracetam with oxyethylidenediphosphononatohydroxygermanium acid and their interferonogenic activities. Abstr. Rep. XX Ukr. Conf. Organic Chemistry. Odessa, 2004, pp. 443.

25. Pat. 66392 Ukraine, (51) МПК (2011.01), A61P 1/16 (2006.01), А61К 31/30 (2006.01), A61K 9/14 (2006.01). Medgerm is biologically active hepatoprotective agent / O.L. Tymchishin, V.V. Godovan, V.Y. Kresyun, I.I. Seifullina, E.E. Martsinko. - Bull. №24. 26.11.2011.

26. Pat. 20555 Ukraine, (19)UA, (51) МПК (2006), А61К 35/30. The method of Pharmacological correction of a craniocereberal trauma / Lukyanchuk V.D., Seyfullina I.I., Vysotsky A.A., Martsinko E.E., Pesaroglo O.G. Bull. №1. 15.01.2007.

27. Pat. 71812 Ukraine, МПК (2012.01) A61P 9/00 A61K 33/00. Potassium bis(citrato)germanate (IV), that shows the antiischemic activity / V.D. Lukyanchuk, I.O. Zhitina, I.I. Seifullina, E.E. Martsinko. - Bull. № 14 